$\operatorname{cocos}$ (1997), 12, 54 - 7.1

Printed in Sri Lanka

\title{
USE OF COIR DUST ON THE PRODUCTIVITY OF COCONUT ON SANDY SOILS
}

\author{
L P Vidhana Arachchi and L L W Somasiri
}

Coconut Research Institute, Lunuwila, Sri Lanka

\begin{abstract}
Sandy soils in the coconut triangle often impose limitations such as poor nutrient retention and moisture availability on the growth of the coconut palm. The physical properties of such soils has to be improved for increasing coconut production. Incorporation of coir dust into soils, which is an organic waste of coconut fibre industry is one of the options. A series of laboratory experiments were conducted to evaluate the capability of coir dust of different age to retain water and nutrient and to investigate the suitable mixing ratio of coir dust and soil to ameliorate the moisture status and pore size distribution of the sandy soils. Soil physical characters of coir dust/ sand mixtures such as pore size distribution, capillary rise, water retention and reduction pattern of different ratio of coir dust and soil were determined. Chemical characteristics of coir dust were also determined to study its environmental sustainability. Chemical characteristics showed that coir dusts are poor in nutritional value but high in nutrient retention capacity and it is highly resistant to environmental biodegradation. The available water capacity measured in coir dust aged from 0 to 20 years indicated that the quantity of available water increased from $122.7 \%$ in fresh to $222.4 \%$ in 20 years old mate rial $(g / g)$. The increase in available water showed a linear trend with a age of coir dust $(r=0.913 ; P<0.001)$ and the rate was $5 \%$ per annum. The water content at field capacity ( $10 \mathrm{kPa}$ suction) progressively increased up to the application rate of $21,000 \mathrm{~kg}$ coir dust/ha and thereafter remained constant up to the rate of $62,000 \mathrm{~kg}$ coir dust/ha beyond which it again gradually increased. The results suggest that the optinum rate of coir dust incorporation into sandy soil is $21,000 \mathrm{~kg}$ coir dust/ha $(6.3 \%$ or $1: 15 \mathrm{CD} / \mathrm{sand}$; $\mathrm{vol} / \mathrm{vol})$ and the use of old coir dust up to 20 years is more beneficial for amelioration of soil physical and chemical characteristics when compared to fresh coir dust.
\end{abstract}




\section{INTRODUCTION}

Coconut (Cocos nucifera $L_{\text {. }}$ ) is one of the major plantation crops in Sri Lanka which covers about 416,000 ha (CDA, 1991) and is cultivated on different types of soils with diverse moisture regimes (Somasiri et al., 1994; Vidhana Arachchi 1996). The surface layer of most soils in the coastal planes and the alluvial planes are sandy in nature. The colluvial soils that occur in the mantled plane is also sandy up to about $60 \mathrm{~cm}$ depth (Somasiri et al., 1994). The extent of these soils in the coconut growing areas is quite considerable. The water retention and nutrient status of the surface layer (up to 20 $\mathrm{cm}$ depth from the surface) of these sandy soils are poorer than that of sub soil layers $(>20 \mathrm{~cm})$ which results in growth retardation of coconut seedlings (Vidhana Arachchi, 1996). The sandy nature of these soil leads to nutrient leaching and results in growth retardation of coconut seedlings. Coconut grown on drought susceptible soils except sandy soils are also often subjected to periodic moisture deficit during the dry season resulting in a setback in the growth of young palms and reduction of the yield of bearing palms.

Coir dust/husk burial is the one of options available for moisture conservation in drought susceptible coconut lands which is presently recommended by the Coconut Research Institute (Liyanage et al., 1993). However investigations on the effect of soil moisture conservation in coconut lands by incorporating organic matter is scanty and not well documented. Coir dust which is a major by-product in coconut fibre industry could be used to maintain and improve the organic matter content of depleted soils (Vidhana Arachchi and Jayasekera, 1988). Also coir dust is a spongy material which can absorb ample quantity of water compared to its weight (Vidhana Arachchi and Jayasekara, 1988; Vidhana Arachchi and Somasiri, 1993; Van Holm, 1993). Nevertheless, the coir dust is not used in large quantities as a mulch or incorporation into soil as it could act as a breeding ground for black beetle due to its slow decomposition (Santhirasegaram, 1965). This situation leads to collection of huge heaps of coir dust of different ages near fibre mills causing environmental pollution (Van Holm, 1993). Currently, there is a trend for exporting coir dust in the form of briquettes for which only the materials which less than 3 years old are taken. Still the old heaps remain unused.

Objectives of this study were to (1) evaluate the capability of coir dust.to retain water and nutrient with its age and (11) investigate the suitable ratio of soils to coir dust for improving the pore size distribution and moisture status of coconut growing sandy soils. 


\section{MATERIALS AND METHODS}

\section{Soil and coir dust}

Low productive coconut growing sandy soils in Kajugahalanda estate, Madampe in the Low Country Intermediate Zone $\left(08^{\circ} 02 \mathrm{~N}, 79^{\circ} 50 \mathrm{E}\right.$; $35 \mathrm{~m}$ altitude) of Sri Lanka was selected for the study. The soils is classified as Sudu series which belongs to the great soil group of Regosol. The texture of soils was sandy and soils were collected upto $15 \mathrm{~cm}$ depth and air dried for two days (moisture content $1.3 \pm 0.08 \%$ ). Coir dust (CD) of different ages were sampled from heaps near a mill at Lunuwila. Coir dust (MC\% $73 \pm$ $12 \%$ ) was also air dried for two days and mixed thoroughly with soils so that the mixtures consisted of coir dusts equivalent to $4.8 \%, 6.3 \%, 7.2 \%, 7.4 \%$, $9.1 \%, 11.1 \%, 16.7 \%, 20 \%, 33.3 \%$ and $50 \%$ on volume basis. In the case of field application of coir dust soil mixtures, the use of volume basis is quite appropriate rather than the use of weight basis.

\section{Physical properties}

The following physical properties were measured in each of the mixtures, (a) bulk density by disturbed core sample method by giving constant vibration for packing in the steel core samplers of $7.5 \mathrm{~cm}$ in diameter and 5 $\mathrm{cm}$ in height (Blake and Hartge, 1986), (b) total porosity and pore size distribution using moisture characteristic curves (Danielson and Sutherland, 1986), (c) water retention characteristics using pressure plate apparatus (Cassel and Nielsen, 1986) and (d) texture analysis by hydrometer method (Gee and Buder, 1986).

Each mixture was compacted by applying constant vibration into a 5 $\mathrm{cm}$ diameter glass tube of which the end was covered with a cheese cloth. The covered end of glass tube was contacted with surface of water filled beaker to find out the capillary height of water in different mixtures. Each mixture was kept in an oven at $40^{\circ} \mathrm{C}$ for different time intervals to study moisture reduction pattern which was measured by the gravimetric method. Fifteen replicates of each mixture were used for the analysis of soil physical properties.

\section{Chemical analysis}

The $\mathrm{pH}$ value of coir dust was measured in a coir dust/distilled water mixture prepared at $1: 5 \mathrm{~V} / \mathrm{V}$ ratio. Measurements were taken by immersing a combined glass electrode attached to a pH meter into the mix- 
ture. The conductivity of the coir dust/water mixtures prepared at $1: 5 \mathrm{v} / \mathrm{v}$ ratio was measured by conductivity meter.

The nutrient retention capacity was measured by the following procedure. Five grams of coir dust was taken to a Bukner funnel fitted to a flask and leached with five portions of $30 \mathrm{ml}$ of $1 \mathrm{M}$ ammonium acetate solution (pH 7.0) and the leachate was discarded. Then the coir dust was washed with 5 portions of $30 \mathrm{ml}$ of $98 \%$ ethyl alcohol and the washings were discarded. Finally, the coir dust was leached with three portions of $100 \mathrm{ml}$ of $1 \mathrm{M} \mathrm{NaCl}$ solution and the $\mathrm{NH}_{4}{ }^{+}$content of the resulting leachate was determined.

Mineral content of coir dust was determined by ashing a sample of 1 $\mathrm{g}$ (previously dried at $70 \mathrm{C}^{\circ}$ ) at $500 \mathrm{C}^{\circ}$ and dissolving the resultant ash in $5 \%$ $\mathrm{HCl}$ solution. Phosphorous was determined by. molybdenum blue colour method (Murphy and Riley, 1962) Sodium, potassium, calcium and magnesium were determined by atomic absorption spectrophotometer. Total nitrogen was determined by digesting $1 \mathrm{~g}$ of dried coir dust with $10 \mathrm{ml}$ of $4 \% \mathrm{Se} /$ $\mathrm{H}_{2} \mathrm{SO}_{4}$ and $2 \mathrm{~g}$ of Na $\mathrm{SO}_{4}$ at $380 \mathrm{C}^{\circ}$ followed by Kjeldhal distillation of $\mathrm{NH}_{3}$ into $4 \%$ boric acid.

\section{RESULTS AND DISCUSSION}

\section{Moisture retention of sand:coir dust mixtures}

The moisture retention of sandy soil progressively increased up to the incorporation ratio of $6.3 \% \mathrm{CD}$ or $15: 1$ sand/CD (vol/vol) equivalent to $21,000 \mathrm{~kg} \mathrm{CD} / \mathrm{ha}$ into sandy soils and there after remained constant upto the incorporation ratio of $20 \% \mathrm{CD}(62,000 \mathrm{~kg} C D / \mathrm{ha}$ incorporation into about $10 \mathrm{~cm}$ depth) beyond which it increased again (Fig. $1 \& 2$ ). Application of $\mathrm{CD}$ beyond the rate of $62,000 \mathrm{~kg} / \mathrm{ha}$ in the field is not profitable due to difficulty in handling. Similar study was conducted by Vidhana Arachchi and Nor (1994 ${ }_{a}$ ) and reported that incorporation of oil palm sludge into sandy loam soil at different rates produced different soil structural improvements and $15 \%$ amendment was the optimum rate which improved soil physical condition than high rates. Incorporation of organic matter can improve soil structure resulted in increasing water holding capacity (Vidhana Arachchi and Nor, 1994; Mapa, 1995). In addition, incorporation of organic matter into soils in proper ratio can enhance moisture retention by blocking of macro pores of sandy soils which can result in increasing number of many micropores (Vidhana Arachchi and Nor, 1994 ${ }_{\mathrm{a}}$ ) which are responsible for conserving 


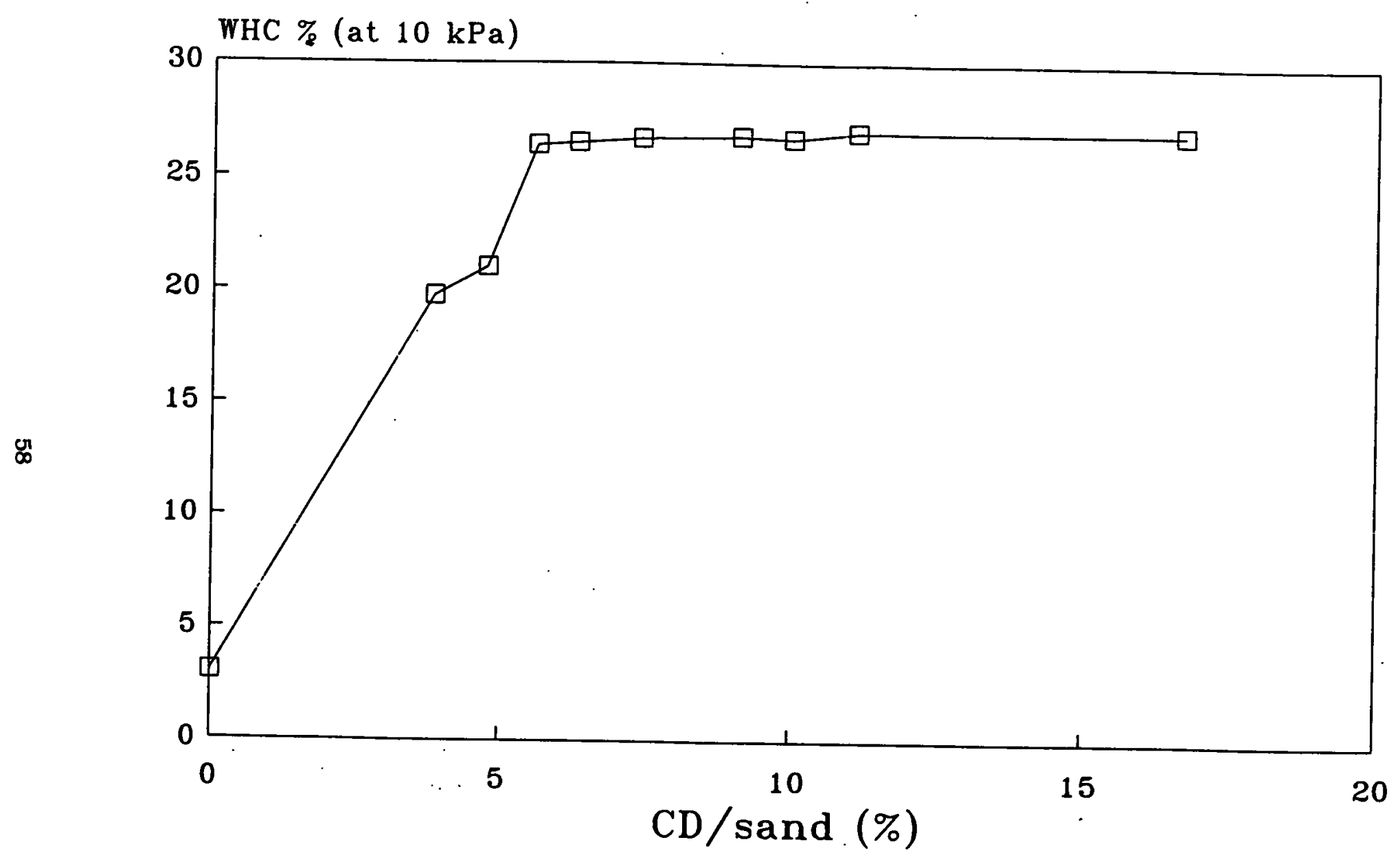

Figure 1 Moisture retention of low rates of $\mathrm{CD} /$ sand mixtures 


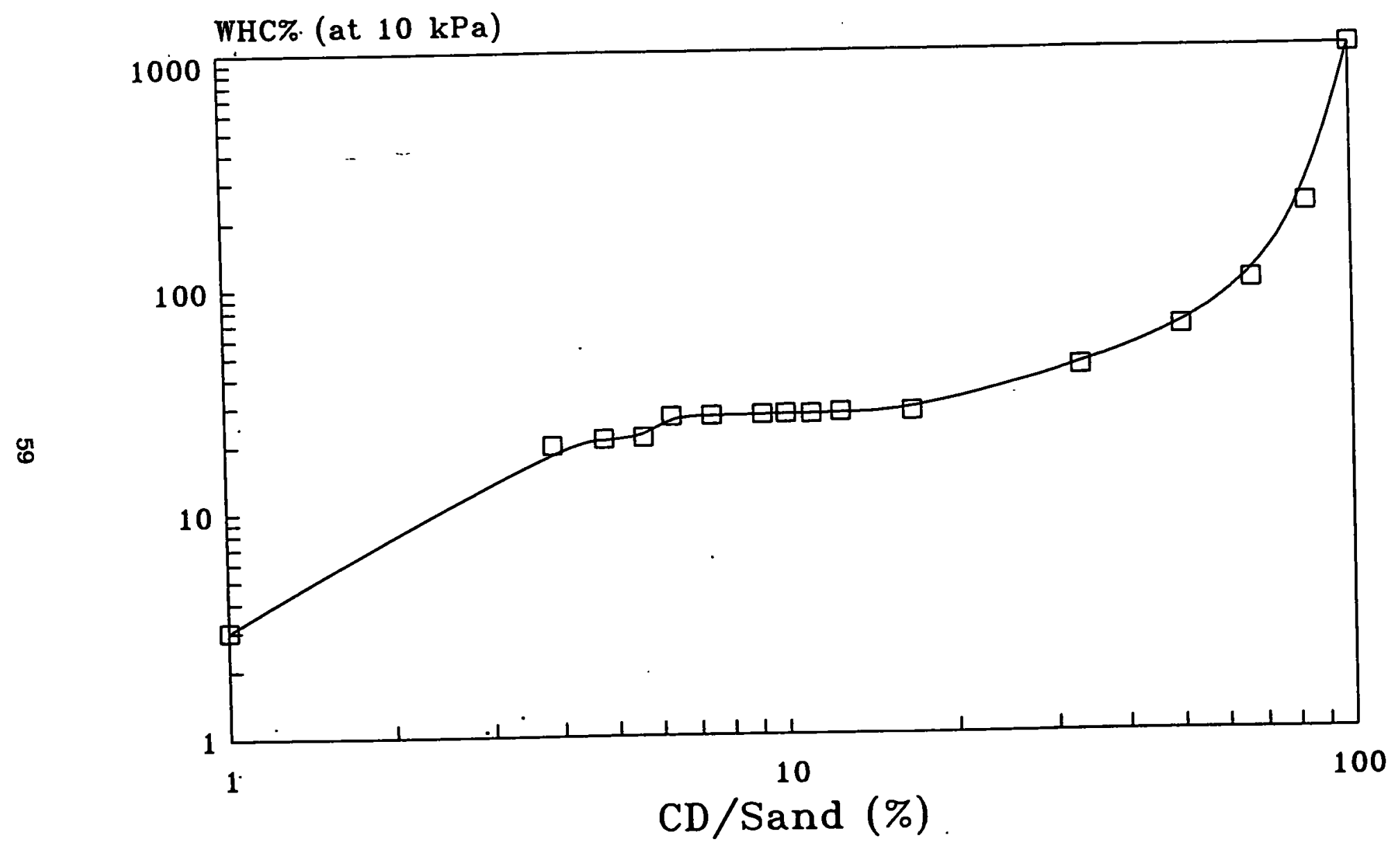

Figure 2 Moisture retention of various $\mathrm{CD} /$ sand mixtures 
soil moisture in longer duration (Brady 1990). Improved soil structure by proper organic matter incorporation also reduces emission of green house gasses (Vidhana Arachchi and Nor, 1994). Improvement of not only soil physical conditions but also the soil nutritional status can be expected by proper incorporation of organic matter. Moreover, Vidhana Arachchi and Nor $\left(1994_{b}\right)$ showed that incorporation of oil palm sludge into soils resulted in better vigor of oil palm seedlings.

\section{Moisture depletion pattern of sand:coir dust mixtures}

The moisture depletion pattern or sand/CD mixtures of different ratios indicate the ability of each mixture to retain moisture during dry periods.

Laboratory studies on moisture reduction pattern at $40^{\circ} \mathrm{C}$ revealed that the pure sand tends to lose a greater quantity of moisture with time compared to $C D /$ sand mixtures. After mixing $C D$ with sandy soil, loss of moisture at $40^{\circ} \mathrm{C}$ decreased up to $8 \% \mathrm{CD}$ incorporation $(26,500 \mathrm{~kg} \mathrm{CD} / \mathrm{ha})$. The results indicated that $6.3 \% \mathrm{CD}$ incorporation $(21,000 \mathrm{~kg} \mathrm{CD} / \mathrm{ha})$ tend to minimize the moisture reduction compared to other ratios of coir dust sand (Fig.3 \& 4). Therefore, the $6.3 \%$ Sand/CD ratio could have proper proportionate of macro to micropores. Optimum conditions of this particular rate would have beneficial effect on crop production. On the other hand, Glauser et al. (1988) reported that the size of the pores affected the movement and distribution of water and air in the soil which is a major factor affecting plant growth. Hence investigation of pore size distribution in coir dust sand mixture is essential to interpret the above results.

\section{Pore size distribution and water capillary height of different mixtures}

Moisture availability $(0.97 \%)$ in soils that was used for this study is low which can be attributed due to the very low clay content $(<10 \%)$. Capillary retention of water in sandy soils is very poor and due to their high drainage ability, nutrient loss can frequently be taken place (Brady, 1990). Therefore, moisture and nutrient retention capacity of sandy soils can be enhanced either by fertigation or soil moisture conservation practices (Uthaian et al., 1993). Their high sand percentage (95.24\%) brings on large macropores volume resulted in high aeration capacity. Joshua (1985) reported that aeration is responsible for maintaining the availability of oxygen in the soil, because of its direct involvement in respiration (Landon, 1984). Nevertheless, Vidhana Arachchi (1996) reported that the ratio of macro to micro pores 


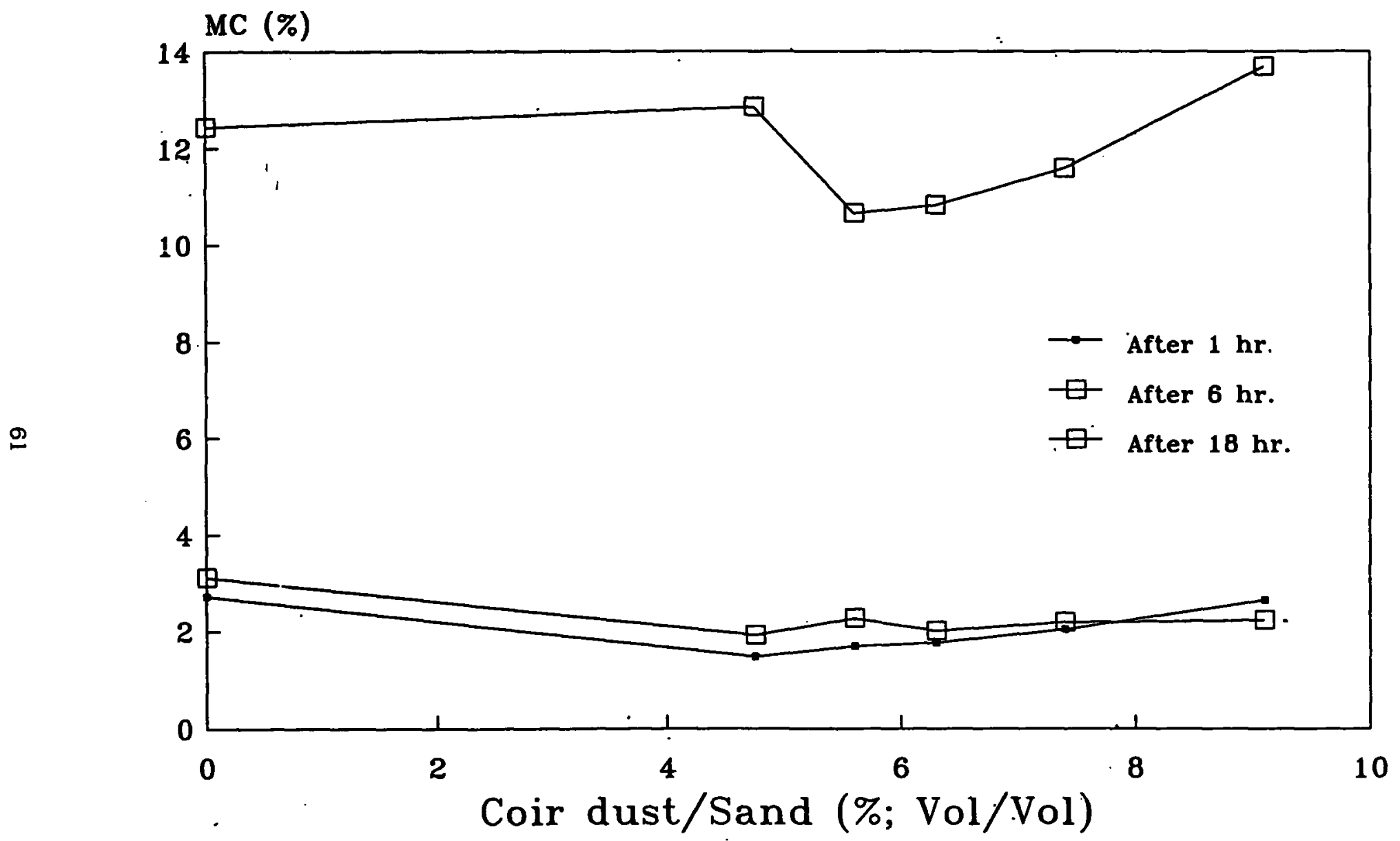

Figure 3 Moisture reduction pattern of low rates of $\mathrm{CD} /$ sand 


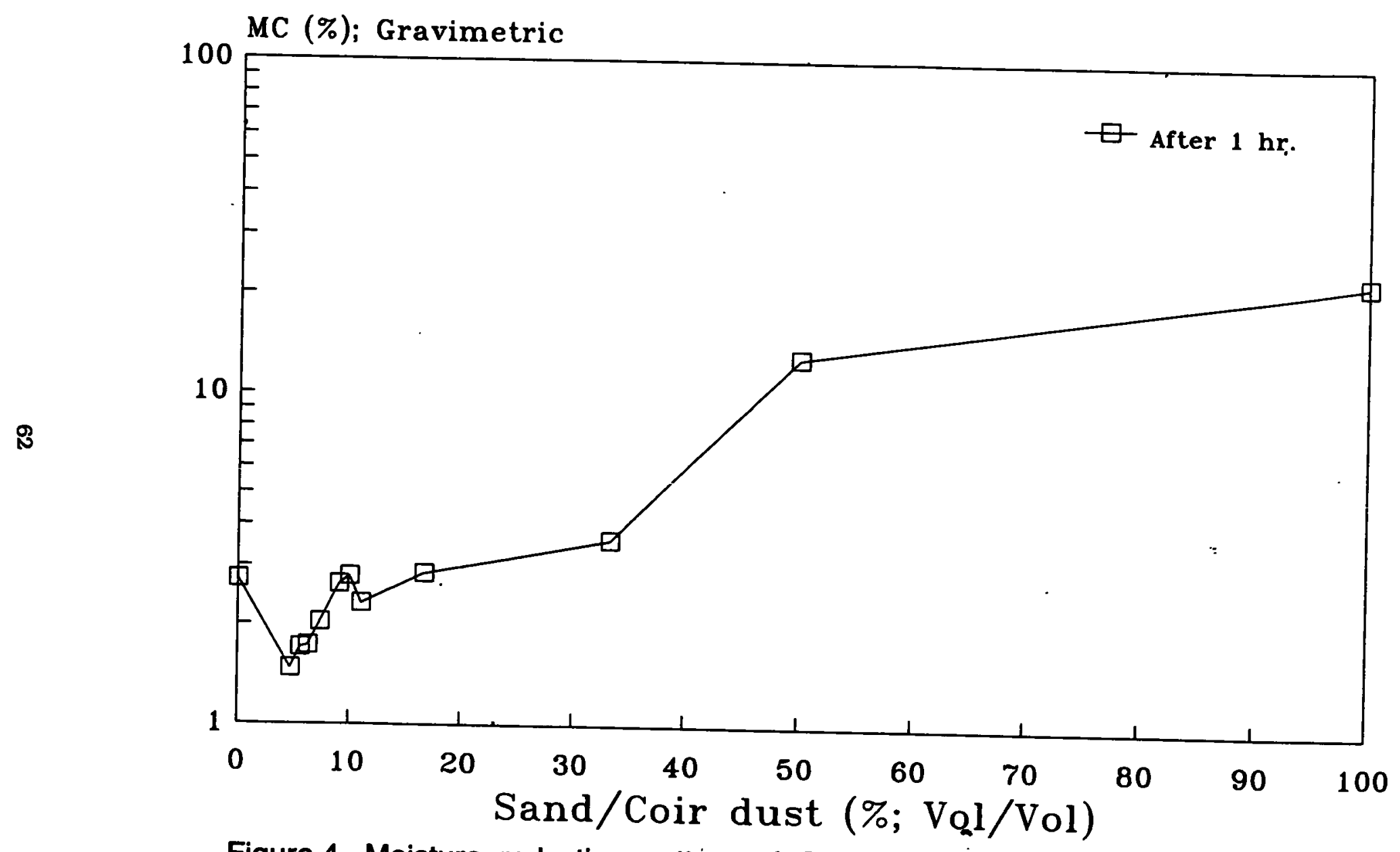

Figure 4 Moisture reduction pattern of $C D /$ sand mixtures 
greater than 3 in sandy soils (>75\% sand) which is one of the constraints on performance of the coconut palm. Such soils should be reclaimed in a suitable manner prior to use for agricultural purposes. Therefore, incorporation of organic matter such as coir dust would be much suitable for reclamation of sandy soils as they can withstand against the environmental degradation compared to the other organic materials (Van Holm, 1993).

The highest capillary height and the lowest capillary radius were observed in 6.3\% CD incorporation compared to other treatments (Table 2). Soils with low capillary radius promote their water and nutrient retention in longer duration and slow nutrient leaching can also be expected in this type of soils (Brady, 1990).

The total porosity of $\mathrm{CD}$ amended sand compared to that of pure sand indicated that aeration is improved following the treatments in addition to the increase in moisture retention. Those improyements in soil physical properties could conduce root growth and proliferation. Thus, by incorporating coir dust to surface layer of sandy soils, its physical properties could be amended to suit growth of nitrogen fixing creeping cover crops (eg. Pueraria phasioloide) which could promote soil fertility. Zakaria (1990) also stated that incorporation of organic matter into soil improved chemical and physical properties of soil such as water retention, soil aeration and soil structure and promoted root proliferation.

\section{Different ages of coir dust}

Evaluation of water retention of different ages of $C D(0-20 \mathrm{yrs})$ revealed that water retention increased with the age of $C D$ (up to $20 \mathrm{yrs}$ ) compared to fresh $\mathrm{CD}$ (Table 3). Also moisture retention became almost constant in all CD samples after $500 \mathrm{kPa}$ suction (Fig. 5). Even at this stage, $C D$ has much potential to conserve more moisture in their pores which could help to maintain soil moisture for longer period of the dry seasons. The available water capacity $(10-1500 \mathrm{kPa}$ ) increased from $122.7 \%$ in fresh $C D$ to $222.4 \%$ in 20 yrs old $C D(w / w)$. The increase in available water showed a linear trend $(r=0.913)$ and the rate of increase was $5.0 \%$ per annum (Table 3 ).

Greater moisture availability in old coir dust compared to fresh coir dust indicated a practical benefit. In addition, more than one year old coir dust is not toxic for plant growth and has high resistance against biodegradation (Van Holm, 1993). Therefore, incorporated coir dust can exists in the field for a long period. Most coconut growers are not willing to use old coir 
Table 1. Mean chemical characteristics of coir dust (CD) of different ages

Properties Fresh CD

$\mathrm{pH}(1: 5 \mathrm{v} / \mathrm{v}) \quad 5.1 \pm 0.3$

$\mathrm{EC}(1: 5 \mathrm{v} / \mathrm{v}) \quad 709 \pm 65$

$\mathrm{m} \mathrm{mho} / \mathrm{cm}$

CEC

$\mathrm{me} / 100 \mathrm{~g}$

Total N

(\% DM)

Total P

(\% DM)

Total K

(\% DM)

Total Ca

(\% DM)

Total Mg

(\% DM)

$74 \pm 18$
10 years old $C D 20$ years old $C D$

$5.5 \pm 0.4$

$5.5 \pm 0.4$

$166 \pm 40$

$196 \pm 35$

$84 \pm 15$

$101 \pm 17$

$84 \pm 15$

$0.56 \pm 0.04$

$0.71 \pm 0.03$

$0.31 \pm 0.05$

$0.03 \pm 0.01$

$0.03 \pm 0.01$

$0.04 \pm 0.01$

$1.46 \pm 0.25$

$0.83 \pm 0.15$

$0.62 \pm 0.13$

$0.27 \pm 0.01$

$0.33 \pm 0.01$

$0.20 \pm 0.01$

$0.27 \pm 0.01$

$0.17 \pm 0.03$

$0.21 \pm 0.15$

EC-Electrical conductivity; CEC-Cation exchange capacity $\pm S D n=15$ 
Table 2 Total porosity, capillary height and capillary radius in Jow rates of $\mathrm{CD} /$ sand mixtures

\begin{tabular}{|c|c|c|c|}
\hline $\begin{array}{l}\text { Mixture (\%) } \\
\text { CD/(sand+CD) } \\
\text { (vol/vol) }\end{array}$ & $\begin{array}{l}\text { Total } \\
\text { porosity (\%) }\end{array}$ & $\begin{array}{l}\text { Mean capillary } \\
\text { height }(\mathrm{cm})\end{array}$ & $\begin{array}{l}\text { Mean c } \\
\text { radius ( }\end{array}$ \\
\hline 4.76 & $35.57 \pm 4.8$ & $16.2 \pm 2.9$ & $38 \pm 6$ \\
\hline 5.6 & $35.69 \pm 6.5$ & $15.3 \pm 2.3$ & $40 \pm 5$ \\
\hline 6.3 & $36.33 \pm 5.3$ & $21.3 \pm 3.3$ & $29 \pm 4$ \\
\hline 7.14 & $36.11 \pm 3.6$ & $14.2 \pm 1.0$ & $43 \pm 8$ \\
\hline 7.4 & $35.55 \pm 4.7$ & $12.7 \pm 3.7$ & $48 \pm 4$ \\
\hline Only sand & $32.80 \pm 8.0$ & $14.4 \pm 7.8$ & $44 \pm 5$ \\
\hline LSD & $\begin{array}{l}2.35 \\
* * *\end{array}$ & $\begin{array}{l}2.12 \\
*\end{array}$ & $\begin{array}{l}3.68 \\
*\end{array}$ \\
\hline CV\% & 15 & 13 & 18 \\
\hline
\end{tabular}

$\mathrm{p}<0.001$ - ***; $^{*}<0.01$ - * $^{*}$ 
-Table 3. Water retention in different ages of CD at 10-1500 kPa suction.

$\begin{array}{rrr}\text { Age of } \mathrm{CD} \quad 10 \mathrm{kpa} \quad 30 \mathrm{kpa} \quad 1500 \mathrm{kpa} & \begin{array}{l}\text { Available water } \\ \text { capacity } \\ (10-1500 \mathrm{kPa})\end{array}\end{array}$

<-...................--Gravimetric moisture (\%)-..............................>

$\begin{array}{lllll}\text { Fresh } & 337.7 & 289.3 & 214.99 & 122.71 \\ & \pm & \pm & \pm & \\ & 14.2 & 6.2 & 2.8 & \\ & & & & \\ 10 \text { Years. } & 615.3 & 453.3 & 408.45 & 206.85 \\ & \pm & \pm & \pm & \\ & 1.0 & 16.6 & 6.3 & \\ & & & & \\ 20 \text { years } & 522.1 & 408.5 & 299.65 & 222.45 \\ & \pm & \pm & \pm & \\ & 9.61 & 19.0 & 15.6 & \\ & & & & \end{array}$




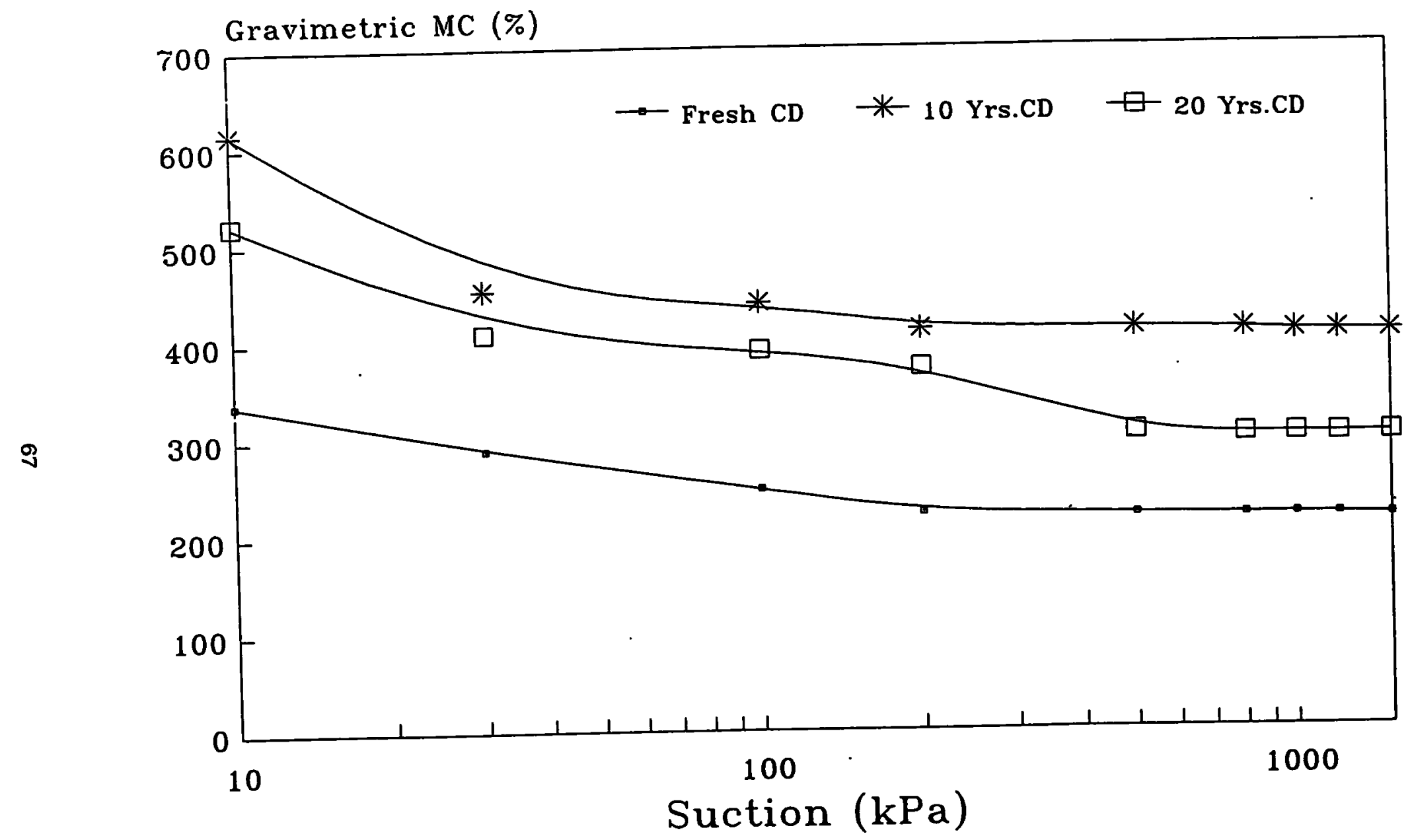

Fig. 5 Moisture characteristic curves of coir dust 
dust for soil amelioration on the concept that those are of low quality as far as the moisture retention is concerned. But the present study indicates that old $\mathrm{CD}$ is a better material for soil amelioration (Fig.5, Table 3).

\section{Chemical properties of coir dust}

Chemical properties of different ages of coir dust indicated in Table 1 shows that total nitrogen content of coir dust increased with time. This could be due to either accumulation of nitrogen through rain water or release of nitrogen compounds during the process of mineralization when the decomposition takes place (Michael and Bjorn, 1988; Vidhana Arachchi and Nor, 1994b). However, mineralization studies conducted by Van Holm (1993) showed that coir dust in soil demonstrated a very slow decomposition and low mineralization after high and/or continuous application. Results also showed that potassium content was fairly high in fresh coir dust but gradually decreased with time (Table 1) which could be due to leaching during the rainy season (Brady, 1990). The effect of leaching is also evident by the decrease of electrical conductivity with aging which could be due to removal of soluble salts. However, phosphate, magnesium and calcium content of coir dust showed only a slight increasing trend with time indicating that they were not subjected to considerable leaching (Table 1). It is also interesting to note that nutrient retention capacity of coir dust increases with aging of coir dust (Table 1). Similar results of chemical aspects of coir dust and their releasing power with time was observed by Van Holm (1993). Increasing trend of cation exchange capacity with the age of coir dust could be attributed to release of free organic acid perhaps occurred due to partial decomposition of coir dust (Table 1). Increasing trend in fulvic acid and humic acid with aging of coir dust has been observed by Van Holm (1993). As the nutrient retention capacity of coir dust is very high compared to that of sandy soils, its incorporation can improve nutrient retention capacity of soils. Aged coir dust could be much better in improving nutrient retention capacity in soils than fresh coir dust.

It is very much important that the water and nutrient retention of the top layer of sandy soils be improved for a sustainable coconut cultivation. The results of the present study shows that incorporation of waste coir dust into the sandy soils is much beneficial in ameliorating their physical conditions, moisture status and nutrient retention capacity. Also, incorporation of waste coir dust into soils is very economical and practical method that could be adopted in coconut lands. 


\section{CONCLUSION}

The application of coir dust at the ratio of $6.3 \% \mathrm{CD}$ (equivalent to field application of $21,000 \mathrm{~kg} / \mathrm{ha}$ ) to coconut lands having sands in the top layer is beneficial as it improves moisture and nutrient retention capacities and physical properties of soils. Use of old $\mathrm{CD}$ for soil amelioration is much better than the use of fresh $C D$ as the former can retain a greater quantity of water as well as nutrients compared to the latter.

\section{ACKNOWLEDGEMENTS}

Authors wish to thank to the staff of the Soil and Plant Nutrition Division of the Coconut Research Institute, Lunuwila for their invaluable assistant in conducting laboratory experiments.

\section{REFERENCES}

Blake, G.R and Hartge, K. H. (1986). Bulk density: Core methods, In: Method of soil analysis (Amold Klute et.), Agronomy, 9 (part 1), 364-366. Madi son. Wisconshin: Am. Soc. of Agron.

Cassel, D.K. and Nielson, D. R. (1986). Field capacity and available water capacity. In: Method of soil analysis (Arnold Klute ed.). Agronomy, 9 (part 1), 901-924 Madson, Wisconsin; Am. Soc. of Agron.

CDA (1991). Sri Lanka coconut statistics, Coconut Development Aıthority, Sri Lanka.

Gee, G.W and Bauder, J. W. (1986). Particle size analysis (Hydrometer method) In:Method of soil analysis(Arnold Klute ed.),Agronomy 9(part1), 404. Madison Wisconsin; Am. Soc. of Agron.

Glauser, R.H.E. Doner and Paul, E.A. (1968). Soil aggregate stability was a function of particle size in sludge treated soil, Soil Science, 146: 37-43.

Landon, J. R. (1984). Booker Tropical Soil Mannual. Booker Agricultural International Limited, Pitman Press Ltd., Bath England. 450p.

Liyanage, L. V. K. (1987). Moisture conservation in coconut lands. Coconut Cultivation Board, 1: 14-18. 
Liyanage, M de S, Jayasekera, K. S. and Fernandopulle M.N (1993). Effect of application of coconut husk and coir dust on the yield of coconut. Cocos,9: 15-23.

Mahindapala,R.(1990).Activities of the Coconut Research Institute Coconut Bulletin., Vol. 7 1/2: 3.

Mapa R. B. and Bodhinayake W. L. (1988). Characterization of soil moisture retention relationship in Non-calcic Brown soils (Haplustalfs). Tropical Agriculturist, Sri Lanka, 144: 145-153.

Michael, A. M. and Bjorn Berg. (1988), release of carbon and nitrogen from decomposing roots of red clover as affected by liming of soil. Plant and Soil, 105: 149-152.

Murphy, J. and Riley, J. P. (1962). A modified single solution method for the determination of phosphate in natural waters. Analytica Chimica Acta, 27: 31-36.

Sanielson, R.E and Sutherland, P. L. (1986). Total porosity and pore size distribution. In Method of soil analysis (Arnold Klute ed.). Agronomy, 9 (part 1), 444-450. Madison Wisconsin; Am. Soc. of Agron.

Thompson, A.L., C.J. Gentzer and Hammer, R. D. (1992). Productivity of a claypan soil under rain-fed and irrigated condition., J. Soil andWater Con., 47, 5: 405-410.

Somasiri L. L. W., Nadarajah, N., Amarasiri, L., and Gunathilake, H. A. (1994). Land suitability assessment of coconut survey area in the coconut tri angle. Occasional Publication Series 3. The Coconut Research In stitute, Sri Lanka.

Santhirasegaram, K. (1965). "Dry dust" from coconut fibre mills a useful soil ameliorant., Ceylon Cocon. Quar., 16: 85-98.

Uthaian,B. C.,Indiresh, K. M. and Prabhakara Shetty, T. K. (1993). Prelimi nary studieg on the effect of mulches and irrigation on growth of young coconut plants in Coastal Karnataka. Indian Cocon. Journal, 24: 5-9.

Van Holm L. Ir. (1993). A report on Coir dust as a growing medium presented to the 7th Floricultural Symposium. Colombo. Biological nitrogen 
fixation project,Institute of Fundamental Studies, Hantana, Kandy, Sri Lanka.

Vidhana Arachchi, L.P and Jayasekara K. S. (1988). Coir dust to improve coconut production., Antnual Sessions of the Sri Lanka association for the Advancement of Science, B-10: 32.

Vidhana Arachchi, L.P and Somasin, L. L. W. (1993). Efficient use of coir dust on Sudu series soil., Annual Sessions of the Sri Lanka association for the Advancement of Science, B-45: 73.

Vidhana Arachchi, L. P. and Nor Y. M. (1994a). Influence of palm oil sludge on physical properties of soil and growth characteristics of oil palm seed lings (Elaeis guineensis Jacq.), Trop. Agric. (Trinidad), 71: 95-99.

Vidhana Arachchi, L. P. and Nor Y. M. (1994b). Nitrogen dynamics of palm oil sludge-urea-amended soil on the growth of oil palm seedlings (Elaeis guineensis Jacq.). Trop. Agric. (Trinidad), 71: 260-265.

Vidhana Arachchi, L. P. and Nor Y. M. (1994c). Emission of nitrous oxide, nitrogen and methane from palm oil sludge-amended soil. Tropical Agri cultural Research, Sri Lanka, 6: 148-156.

Vidhana Arachchi, L. P. (1996). Characterization of physical properties of soils and studies on the development of coconut roots. The project report (12/175/1490 submitted to the Council for Agricultural Research Policy (CARP), Sri Lanka.

Vries, I. de (1963). A report on a survey of the resources of the Kelani-Aruvi area Ceylon., 1, 164.

Zakaria, Zin, Z., Dolmet, M. T., Hassan, A. H. and Khalid, H. (1990). Prin ciples and guidelines on land application of POME for the oil palm indus try., The Planter, 66: 71-82. 